\title{
Diagnostic value of a simplified screening test for metabolic syndrome in a Dutch patient cohort with schizophrenia spectrum disorders
}

Citation for published version (APA):

Amzand, S. G., Luteijn, B. L., van der Ven, E., Bogers, J. P., \& Selten, J-P. (2018). Diagnostic value of a simplified screening test for metabolic syndrome in a Dutch patient cohort with schizophrenia spectrum disorders. Australasian Psychiatry, 26(6), 615-618. https://doi.org/10.1177/1039856218779137

Document status and date:

Published: 01/12/2018

DOI:

10.1177/1039856218779137

Document Version:

Publisher's PDF, also known as Version of record

\section{Document license:}

Taverne

Please check the document version of this publication:

- A submitted manuscript is the version of the article upon submission and before peer-review. There can be important differences between the submitted version and the official published version of record.

People interested in the research are advised to contact the author for the final version of the publication, or visit the DOI to the publisher's website.

- The final author version and the galley proof are versions of the publication after peer review.

- The final published version features the final layout of the paper including the volume, issue and page numbers.

Link to publication

\footnotetext{
General rights rights.

- You may freely distribute the URL identifying the publication in the public portal. please follow below link for the End User Agreement:

www.umlib.nl/taverne-license

Take down policy

If you believe that this document breaches copyright please contact us at:

repository@maastrichtuniversity.nl

providing details and we will investigate your claim.
}

Copyright and moral rights for the publications made accessible in the public portal are retained by the authors and/or other copyright owners and it is a condition of accessing publications that users recognise and abide by the legal requirements associated with these

- Users may download and print one copy of any publication from the public portal for the purpose of private study or research.

- You may not further distribute the material or use it for any profit-making activity or commercial gain

If the publication is distributed under the terms of Article $25 \mathrm{fa}$ of the Dutch Copyright Act, indicated by the "Taverne" license above, 


\title{
Diagnostic value of a simplified screening test for metabolic syndrome in a Dutch patient cohort with schizophrenia spectrum disorders
}

Australasian Psychiatry 2018, Vol 26(6) 615-618 (C) The Royal Australian and New Zealand College of Psychiatrists 2018 Article reuse guidelines: sagepub.com/journals-permissions DOI: $10.1177 / 1039856218779137$ journals.sagepub.com/home/apy

@SAGE

\begin{abstract}
Salcey G Amzand Psychiatrist, Mental Health Services Delfland, Delft, The Netherlands
Bert L Luteijn Psychiatrist, Mental Health Services Rivierduinen, Gouda, The Netherlands

Els van der Ven Psychologist and Postdoctoral Researcher, Mental Health Services Rivierduinen, Leiden, The Netherlands Jan P Bogers Postdoctoral Researcher and Director residency program, Mental Health Services Rivierduinen, Leiden, The Netherlands
\end{abstract}

Jean-Paul Selten Psychiatrist, Mental Health Services Rivierduinen, Leiden, and; Professor, Maastricht University, Maastricht, The Netherlands

\begin{abstract}
Objective: The aim of this study was to establish the specificity and sensitivity of a simplified screening test based on diastolic blood pressure and waist circumference for predicting metabolic syndrome.

Method: Demographic, anthropometric (waist circumference and systolic and diastolic blood pressure) and laboratory (triglyceride, high-density lipoprotein and fasting glucose) data were collected from a large cohort of Dutch patients with a schizophrenia spectrum disorder in order to determine whether patients fulfilled the Western criteria of the International Diabetes Federation (IDF) for metabolic syndrome. The sensitivity, specificity, likelihood ratio of a positive or negative test outcome and positive and negative predictive values of the simplified test (only waist circumference and diastolic blood pressure) were calculated.

Results: Of 252 recruited patients, 55\% met the IDF criteria for metabolic syndrome. The sensitivity and the specificity of the simplified test were $65 \%$ and $85 \%$, respectively. The likelihood ratios of positive and negative test outcomes were 4.35 and 0.41 , respectively, and the positive and negative predictive values were $87 \%$ and $67 \%$, respectively.

Conclusion: This simplified screening test did not have diagnostic validity for metabolic syndrome in a Dutch cohort of patients with schizophrenia spectrum disorder.
\end{abstract}

Keywords: metabolic syndrome, screening, diagnostic, schizophrenia

$\overbrace{1}$ ardiovascular mortality is a major public-health concern and is partly responsible for the mortality gap between schizophrenia patients and the general population. ${ }^{1}$ A Swedish study demonstrated that cardiovascular disease was responsible for the 50\% increase in mortality due to natural causes as seen in patients with schizophrenia. ${ }^{2}$ Metabolic syndrome, which comprises both obesity and abnormalities in glucose metabolism, lipid metabolism and blood pressure, is strongly correlated with increased rates of cardiovascular morbidity and mortality. ${ }^{3,4}$ The prevalence of metabolic syndrome is two- to fourfold higher in patients with schizophrenia than in the general population. 5,6 This high prevalence is related to the disease itself, with a possible genetic link between schizophrenia and diabetes, and other associated behavioural factors, such as antipsychotic agents, poor diet, smoking and physical inactivity. 7,8 Despite its high prevalence, metabolic syndrome often goes undetected and untreated. ${ }^{9}$

Simplified screening methods may facilitate the detection of metabolic syndrome and increase the likelihood that adequate interventions are initiated. A simplified

Corresponding author:

Salcey G Amzand, Mental Health Services Delfland, Outpatient Clinic for the Elderly, Jorisweg 2, 2612 GA Delft, The

Netherlands.

Email: salceyamzand@gmail.com 
Table 1. Diagnostic criteria for metabolic syndrome according to the International Diabetes Federation 2005

Metabolic syndrome

Abdominal obesity and two or more of the four other criteria

Waist circumference (abdominal obesity)

1. Fasting triglycerides

2. High-density lipoprotein (HDL)

3. Blood pressure

4. Fasting glucose non-invasive screening test, based on anthropometric data, could be useful because it is low in cost, can be performed in the consulting room and is acceptable to patients. In their study of Taiwanese patients, Lin et al. ${ }^{10}$ found that a model based on only two variables - diastolic blood pressure and waist circumference - had $86 \%$ sensitivity and $83 \%$ specificity for detecting metabolic syndrome, defined according to the International Diabetes Federation (IDF) criteria ${ }^{11}$ (see Table 1).

\section{Aim of the study}

The aim of this study was to replicate the findings of Lin et al. ${ }^{10}$ by establishing the specificity and sensitivity of a simplified screening test for predicting metabolic syndrome in a Dutch cohort of patients with schizophrenia, based on diastolic blood pressure ( $\geqslant 85 \mathrm{mmHg}$ ) and waist circumference ( $\geqslant 94 \mathrm{~cm}$ for men and $\geqslant 80 \mathrm{~cm}$ for women) and using the IDF criteria for metabolic syndrome.

\section{Methods}

We recruited patients who were being treated for schizophrenia spectrum disorders, such as schizophrenia, psychosis not otherwise specified and schizoaffective disorders, at our inpatient and outpatient mental-health facility in Gouda, the Netherlands, from January 2007 to December 2011. The catchment area is a mixed urban/ rural region, and the large majority of patients are Dutch natives. Data collection was performed according to a metabolic screening protocol based on the consensus meeting in 2002 in New York City. ${ }^{12}$

Information on demographics and medication was obtained at the first screening visit or, for the large majority of patients, later in the course of the illness. Anthropometric measurements (waist circumference and blood pressure) and laboratory measurements (triglycerides, high-density lipoprotein and fasting glucose) were taken to determine if patients fulfilled the IDF criteria. Age indicates the patient's age at the date of this assessment.
A patient can also meet the IDF criteria if he or she uses medication for abnormal metabolic values, such as antihypertensive medication, lipid-lowering medication and antidiabetic medication. However, as we had insufficient information about the use of these medications, patients who met these criteria were not recognised as such. Lin et al. ${ }^{10}$ adapted the IDF criteria for the Chinese population, using a waist circumference for men of $\geqslant 90 \mathrm{~cm}$ (instead of $\geqslant 94 \mathrm{~cm}$ ). We used the original criterion of a waist circumference $\geqslant 94 \mathrm{~cm}$.

All patients fasted overnight, and blood was collected the following morning at 10 a.m. using an indwelling catheter. Serum glucose, triglycerides and cholesterol were measured at a local laboratory with Hitachi autoanalyzers (Hitachi Modular PPE, Tokyo, Japan). Blood pressure was measured once the patient was seated using the Korotkoff method. Waist circumference was measured at the approximate midpoint between the lower margin of the last palpable rib and the top of the iliac crest according to the World Health Organization expert consultation. ${ }^{13}$ Data were collected by a nurse practitioner, physicians and psychiatrists.

All patients consented to metabolic screening. The researchers had access to anonymised data. All analyses were performed using IBM SPSS Statistics for Windows v19.0 (IBM Corp., Armonk, NY). Chi-square analyses were used to generate test characteristics, including sensitivity, specificity, likelihood ratios for positive and negative test outcomes and positive and negative predictive values.

\section{Results}

We recruited 252 patients, 228 of whom used antipsychotic medication. Table 2 summarises the demographic and clinical characteristics of patients with or without metabolic syndrome. Men were over-represented in both groups $(63 \%)$, as well as in the total population of patients with psychotic disorders. The metabolic syndrome group was significantly older than the non-metabolic syndrome group $(p<0.05)$. 
Table 2. Demographic and clinical characteristics of 252 patients with schizophrenia spectrum disorders in Gouda, the Netherlands, in relation to presence of metabolic syndrome (criteria of International Diabetes Federation)

\begin{tabular}{|c|c|c|c|c|}
\hline \multirow[b]{2}{*}{ Characteristics } & \multicolumn{2}{|c|}{ Non-MetS $(\mathrm{n}=113)$} & \multicolumn{2}{|l|}{ MetS (n=139) } \\
\hline & Male $(n=75)$ & Female $(\mathrm{n}=38)$ & Male $(n=84)$ & Female $(\mathrm{n}=55)$ \\
\hline Age (years) & Mean 37.3 & Mean 41.1 & Mean 43.4 & Mean 47.7 \\
\hline Weight (kg) & 76.7 & 72.3 & 98.7 & 83.9 \\
\hline Waist circumference (cm) & 92.4 & 89.3 & 110.6 & 102.5 \\
\hline Fasting triglycerides (mmol/L) & 1.3 & 1.0 & 2.3 & 2.2 \\
\hline High-density lipoproteins (mmol/L) & 1.3 & 1.6 & 1.0 & 1.2 \\
\hline Systolic blood pressure $(\mathrm{mmHg})$ & 132.5 & 127.9 & 140.6 & 135.5 \\
\hline Diastolic blood pressure (mmHg) & 79.2 & 79.6 & 89.1 & 87.4 \\
\hline Fasting glucose (mmol/L) & 5.3 & 5.1 & 6.0 & 6.2 \\
\hline \multicolumn{5}{|l|}{ Antipsychotic medication, $n(\%)$} \\
\hline None & 7 & 4 & 7 & 6 \\
\hline Olanzapine & 18 & 7 & 19 & 7 \\
\hline Clozapine & 14 & 1 & 21 & 12 \\
\hline Risperidon & 8 & 3 & 9 & 8 \\
\hline Aripiprazol & 0 & 1 & 1 & 1 \\
\hline Quetiapine & 4 & 5 & 7 & 6 \\
\hline First-generation antipsychotics & 24 & 17 & 20 & 15 \\
\hline
\end{tabular}

MetS: metabolic syndrome.

Table 3. Diagnostic validity of a simplified screening test for metabolic syndrome, including waist circumference and diastolic blood pressure, for a sample of 252 patients with a schizophrenia spectrum disorder in Gouda, the Netherlands

\begin{tabular}{llllllll}
\hline & Prevalence & Sensitivity & Specificity & LRP & LRN & PPV & NPV \\
\hline MetS & $55 \%$ & $65 \%$ & $85 \%$ & 4.35 & 0.41 & $84 \%$ & $67 \%$ \\
MetS $^{a}$ & $60 \%$ & $63 \%$ & $90 \%$ & 6.37 & 0.41 & $90 \%$ & $62 \%$
\end{tabular}

aPatients using only atypical antipsychotics.

LRP: likelihood ratio of a positive test; LRN: likelihood ratio of a negative test; PPV: positive predictive value; NPV: negative predictive value.

Table 3 summarises the diagnostic validity of the simplified screening test, using the IDF criteria as the gold standard. The overall prevalence of metabolic syndrome in our study population was $55 \%$. Sensitivity and specificity were $65 \%$ and $85 \%$, respectively.

\section{Discussion}

We were unable to replicate the finding of Lin et al. ${ }^{10}$ that an abnormal waist circumference and increased diastolic blood pressure can identify metabolic syndrome in patients with schizophrenia spectrum disorders. The low sensitivity and likelihood ratios imply that the short screening test may lead to a substantial number of falsenegative results in our population.

The high specificity of the simplified test means that a positive test result is very likely indicative of metabolic syndrome.

Strengths of the study were the large sample size and inclusion from a large Dutch region, with data collection according to a generally used metabolic screening 
protocol, so results can be generalised to ambulatory patients with schizophrenia. We also largely replicated Lin's methods. However, some limitations have to be mentioned. The real proportion of patients with metabolic syndrome was probably higher than we determined, given the lack of information on patients using medication for abnormal metabolic values.

A possible explanation for the discrepant findings is the difference in definition of abnormal waist circumference, a major component of the IDF criteria. ${ }^{14}$ In order to make these criteria more sensitive for detecting metabolic syndrome in the Taiwanese population, Lin et al. ${ }^{10}$ adapted them to require a smaller waist circumference among men. However, we retained the IDF criteria for the European population.

In conclusion, this simplified screening method for metabolic syndrome, based on diastolic blood pressure and waist circumference, had little diagnostic value in this large Dutch sample of chronic schizophrenia patients.

\section{Acknowledgments}

The authors are grateful to the patients who participated in this study. We thank Clary Dogterom and Frits Frencken for data collection and management of the database.

\section{Disclosure}

The authors report no conflict of interest. The authors alone are responsible for the content and writing of the paper.

\section{Funding}

The authors received no financial support for the research, authorship, and/or publication of this article.

\section{References}

1. Saha $S$, Chant $D$ and McGrath J. A systematic review of mortality in schizophrenia Is the differential mortality gap worsening over time. Arch Gen Psychiatry 2007; 64: $1123-1131$.
2. Osby N, Correia N, Brandt L, et al. Mortality and causes of death in schizophrenia in Stockholm county, Sweden. Schizophr Res 2000; 45: 21-28.

3. National Cholesterol Education Program (NCEP) Expert Panel on Detection, Evaluation, and Treatment of High Blood Cholesterol in Adults (Adult Treatment Panel III). Third report of the National Cholesterol Education Program (NCEP) Expert Panel On Detection, Evaluation, and Treatment of High Blood Cholesterol in Adults (Adult Treatment Panel III) final report. Circulation 2002; 106: 3143-3421.

4. Correll CU, Solmi M, Veronese N, et al. Prevalence, incidence and mortality from cardiovascular patients with pooled and specific severe mental illness: a large-scale metaanalysis of 3,211,768 patients and 113,383,368 controls. World Psychiatry 2017; 16 : 163-180.

5. Saari KM, Lindeman SM, Viilo KM, et al. A 4-fold risk of metabolic syndrome in schizophrenia: The Northern Finland 1966 Birth Cohort study. J Clin Psychiatry 2005; 66: 559-563.

6. De Hert MA, van Winkel R, van Eyck D, et al. Prevalence of the metabolic syndrome in patients with schizophrenia treated with antipsychotic medication. Schizophr Res 2006; 83: 87-93.

7. Mitchell AJ, Vancampfort D, Sweers K, van Winkel R, Yu W and De Hert M. Prevalence of metabolic syndrome and metabolic abnormalities in schizophrenia and related disorders - a systematic review and meta-analysis. Schizophr Bull 2013; 38: 306-318.

8. Heald A, Pendlebury J, Anderson S, et al. Lifestyle factors and the metabolic syndrome in schizophrenia: a cross-sectional study. Ann Gen Psychiatry 2017; 16: 12.

9. Ayerbe L, Forgnone I, Addo J, et al. Hypertension risk and clinical care in patients with bipolar disorder or schizophrenia; a systematic review and meta-analysis. J Affect Disord 2018; 225: 665-670.

10. Lin C, Bai Y, Chen J, et al. Easy and low-cost identification of metabolic syndrome in patients treated with second-generation antipsychotics: artificial neuronal network and logistic regression models. J Clin Psychiatry 2010; 71: 225-234.

11. Alberti KGMM, Zimmet $P$ and Shaw J. Metabolic syndrome - a new world-wide definition. A consensus statement from the International Diabetes Federation. Diabet Med 2006; 23: 469-480

12. Marder SR, Essock SM, Miller AL, et al. Physical health monitoring of patients with schizophrenia. Am J Psychiatry 2004; 161: 1334-1349.

13. World Health Organization. Waist circumference and waist-hip ratio: report of a WHO expert consultation. Geneva, 8-11 December 2008. Geneva, Switzerland: World Health Organization.

14. Gray LJ, Yates T, Davies MJ, et al. Defining obesity cut-off points for migrant south Asians. PLoS One 2011; 6: e26464. 